\title{
Diversity, Employee Morale and Customer Satisfaction: The Three Musketeers
}

\author{
Usmani Sania, Kumari Kalpina, and Hussain Javed
}

\begin{abstract}
This study explores the relationship between diversity and customer satisfaction mediated by employee morale. The study was conducted on the frontline employees of 6 multinational fast food restaurant chains and customers of those fast food restaurants in Karachi, Pakistan. The data on diversity and employee morale was collected from employees through self-reported questionnaires while data on customer satisfaction was gathered from customers dining in those restaurants. A convenience based sample of 235 respondents was taken for the study. Exploratory Factor Analysis, Confirmatory Factor Analysis and Structural Equation Modelling were run to test the relationship and significance of the model. The results rejected the mediated relationship of diversity and customer satisfaction but showed positive direct association between diversity and employee morale.
\end{abstract}

Index Terms-Customer satisfaction, diversity, employee morale.

\section{INTRODUCTION}

The reality of today is a diverse workforce. A company with diverse workers serves and competes in a diverse market in a better way [1]. In this era of globalization, workforce diversity is an opportunity for organizations to create a competitive advantage; but, managing diversity often create challenges as different people think and act differently therefore they are receptive to common problems which require assistance for their solution. Employee commitment reflects that employees feel valued for their contribution in achieving organizational goals i.e. the part they play in achieving organizational performance; therefore managing workforce diversity becomes the cornerstone of organizational performance which improves productivity.

Managing diversity can enhance employees' morale which is expressed as the depiction of their attitude, emotions, satisfaction and overall point of view towards their organization. Increased morale will make an employee happier and more productive, and higher productivity will lead to higher performance and increased customer satisfaction. Customer satisfaction is important because it enhances customer retention and ultimately leads to profitability in a company.

This article investigates the effect of cultural diversity of the employees on customer satisfaction mediated through employee morale.

Manuscript received August 28, 2013; revised November 4, 2013.

Usmani Sania is with the Iqra University, Pakistan (e-mail: sania@iqra.edu.pk).

\section{LITERATURE REVIEW}

\section{A. Diversity}

According to Equal Employment Opportunity Commission (EEOC) traditionally, diversity maybe defined as, variations in racio-ethnicity, gender and age. Other definitions are panoramic and involve attitudes, perceptions, and backgrounds of the employees. Further, some have also incorporated people from different hierarchical levels, and functions in the diversity definition. Robinson \& Dechant, [2] state the definition of diversity given by Pillsbury Company as "all the ways in which we differ".

In this competitive global market, companies favour the broadest definition of diversity, a definition which includes variations in gender, backgrounds, racio-ethnicity, age, qualities, physical abilities, sexual orientation, attitudes, and perceptions [2].

Furthermore, Patrick and Kumar [3] explain the notion of diversity as having differences in gender, personality, cognitive style, ethnic group race, tenure, age, education organizational function, and background etc.

Jackson, May, and Whitney [4] defined diversity as the existence of distinctions between members of a common entity. As organizations worldwide become more diverse, organizational life depends upon managing diversity which is based on race, gender, ethnicity, national origin, age, and personality [5].

A diverse workforce is essential for corporate success [6]. Organizations can benefit from and be successful by workforce diversity if they create an organizational environment which is able to attract people from different markets. Diversity when managed effectively encourages competitive advantage by recruiting and selecting the best people for the job from diverse labour markets regardless of their differences in gender, religion, ethnicity, or individualities [7].

Effective management of diversity not only involves recruitment of diverse employees but also their retention [8]. Implementing effective HR practices to deal with the workforce diversity enhances organizational performance [9]; [10]. Effective diversity practices and profits have a strong relationship [11].

Diversity management means creating an equitable working environment where employees perform to their full potential without feeling discriminated [12]. Dynamic companies search for various types of people because it brings multiplicity of interests, talents, and viewpoints [13]. Both employees and customers are adversely affected when organizations fail to value diversity and do not try to eradicate discrimination and injustice in the workplace. Organizations must focus on universal strategies that value 
diverse employees and address comprehensive human resource issues [1].

Diversity enhances innovation, a broad outlook, improved problem identification and description, various options and solutions [8].The notion of diversity embraces recognition and respect. It is a way of recognizing individual differences and understanding that each individual is unique. These differences can be based on everything including political beliefs, religious beliefs, socioeconomic status, and even ideologies. Managing diversity involves moving beyond tolerating the diversity of individuals and accepting and celebrating the rich characteristics of diversity which each person has [3].

Effective diversity management means following practices that involves appreciating and accepting the humanity, natural environment, and interdependence of cultures; giving respect for the individualistic experiences, knowledge, skills, and qualities; recognizing and understanding that discrimination based on personal, cultural, and institutions creates privileges for some while augments difficulties for others; and building associations across differences to work together and eliminate these discriminations [3]. The significance and impact of cultural diversity increased immensely as many organizations moved away from domestic, and international strategies to operate as a global organization [14]. Managers must learn the business etiquettes, cultural traditions, and courtesies of their global counterparts along with understanding their mind-sets, national character, and managerial viewpoints, in order to capture business opportunities for collaboration; thus, diversity can help organizations to enter the international arena [15]; [3].

\section{B. Employee Morale}

Even though the importance of employee morale on performance is highly recognized but there is no consensus on a specific theory or set of factors related to employee morale [16].

The definition of employee morale is mixed with controversies. As there are many writers on this phenomenon so there are numerous definitions [17]. Various studies have identified employee and organizational characteristics which influence morale but morale has been measured by different people in different ways therefore making comparisons across studies difficult. Hence, forming an effective and appropriate strategy to improve employee morale is problematic. A high morale means the employee is satisfied with the job, puts in effort, is creative, takes initiative, is committed to the organization and focuses on achieving organizational goals rather than personal goals. Low morale leads to high skiving, high turnover, unsolved complaints and strikes, thereby encumbering firm's performance [18]. According to Howitt [16], morale is a feeling not a consequence or action, thus it is difficult to quantify it.

Both Lawrence [17] and Hershey [19] state that using terms such as job satisfaction, job frustration, job motivation, job attitudes and group dynamics complicates the definition of morale.

According to the business dictionary [20] employee morale is defined as the depiction of emotions, satisfaction, and overall attitude towards a workplace. Productivity is directly related to morale. Happy employees have high morale while dissatisfied and unhappy employees have low morale. Linz, et al [18] measured employee morale, using job satisfaction, organizational commitment, turnover rates, complaints and employee strikes as a proxy.

\section{Customer Satisfaction}

The significance of customer satisfaction is indisputable. When obtaining customer satisfaction, one needs to look at the possible antecedents and determinants of it [21]. In service industry, employees, customers and other stakeholders interact to yield the ultimate service outcome. As customers are directly involved in the service production function therefore they are called the partial employees. In the service environment managers must have skills to manage both their full-time and partial employees [1].

Focus on customer satisfaction helps to create a baseline standard of performance and successful business management. Customer satisfaction is an indicator of company's profits. It also serves for the establishment and growth of a customer-oriented environment and culture.

Customer satisfaction compares perceived and expected quality of service and leads to post consumption experience. It is a post-purchase assessment of the goods or service relative to a pre-purchase anticipation [22]

Customer satisfaction is the outcome of the customer, the service and the provider of the service. According to Cengiz [22], customer satisfaction is the perception of a customer with respect to the product or service provided by the organization in an effective manner.

\section{Diversity and Employee Morale}

Diversity changes the nature of workplace and relationships among employees. If it is not planned and managed properly then these changes can cause stress and lead to negative working relationships and poor employee morale. Diverse employees may even feel unwelcome in the workplace, hence removing this perception is essential through training, education and organizational activities which will improve work environment and employee morale.

Employees with low morale may have poor relationships with colleagues and managers. Encouraging greater appreciation for diversity can improve their morale. Managers need to change the image of diversity of only abiding by the rules and regulations of equal employment opportunity and present diversity as a means to improve productivity in the global arena.

\section{E. Employee Morale and Customer Satisfaction}

In the business world managers are pushed to keep customers happy, look after them so they remain loyal and buy their products. Employee morale is essential in the pursuit for achieving customer satisfaction. Content employees give high-quality service and exert positive energy and willingness while dealing with their customers. Employee satisfaction is a predictor of customer loyalty while customer loyalty is an important antecedent of financial outcomes. Satisfied employees give a better ROI and stay with the company for long term [23].

Employees with low morale are self-absorbed and are concerned with the internal politics of the company rather than the customer which results in low customer satisfaction 
and net profits. This induces the fear of being redundant and layoffs which further lower their morale [23].

Retaining good people may have an economic impact on the firm but lying off seldom excites employees. Instead it suppresses creativity, discourages risk-taking, and impedes loyalty. If not fired but the fear of being a target imbibes the energy and diverts employee's attention to safeguard their careers. This takes them farther from the success of the organization towards finding new jobs for themselves.

Due to the worldwide recession, organizations replace people with technologies and keep employees only to make up the deficit. People work longer hours with no compensation or appreciation with a fear of becoming the next victim of the economic downturn. Today, employee morale is lower than previously because of lack of funds, resources and managerial distress [23].

With the current situation of the macro-environment, employees are overworked and underpaid. Companies like Sears and Southwest Airlines (USA) have been able to create a linkage between employee satisfaction and customer loyalty. This linkage helps to estimate the company's financial performance [23].

In this global world, the relationships established between the organizations, its employees and its customers are important for a business's success. In the service sector, interpersonal relationships determine the success or failure of the product that employees sell which transforms the way companies manage and measure their performance. Top-level managers now divert their focus on setting profit goals and shift their attention towards frontline workers and customers. Investing in employees and technology that helps front-line workers, revamping recruiting and training, and linking compensation to performance are the factors that lead to profitability and productivity in this new paradigm so managers must pay attention to them in order to be successful [24]. This paper researches upon the effect of diversity on customer satisfaction mediated through employee morale.

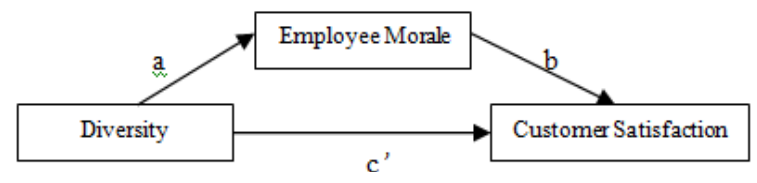

Fig. 1. Hypothetical model.

\section{F. Hypotheses}

H1. Diversity and customer satisfaction have a negative relationship

H2. Diversity and employee morale have a negative relationship

H3. Employee morale and customer satisfaction have a positive relationship

H4. Diversity decreases customer satisfaction when employee morale is controlled

\section{RESEARCH METHODS}

\section{A. Data Sampling}

In this paper the association between customer satisfaction and diversity is examined in the fast food industry of Karachi, Pakistan. The fast food industry of Pakistan comprises of variety of restaurants both local and multinational. The focus of this study is multinational fast food chains operating in Karachi, Pakistan. The fast food chains incorporated include; Pizza Hut (26 branches), Dominos (6 branches), Mc Donald's (11 branches), KFC (18 branches), Hardees (1 branch) and Subway (9 branches).The data was collected from 470 individuals out of which data on diversity and employee morale was collected from 235 employees from these fast food branches while data from 235 customers from these branches was collected therefore the sample size was 235. Convenience based sampling technique was used.

\section{B. Procedures}

All the variables were self- reported therefore attempts were made to deal with common method bias issue in the study by following the recommendations of Podsakoff, MacKenzie, Lee, and Podsakoff [25]. Instrument was used to collect data on the perceptions for diversity, employee morale and customer satisfaction.

\section{Measures}

\section{1) Diversity}

Perceptions to diversity was measured using 20 items from Workplace Diversity Survey (WDS) created by De Meuse and Hostager [26]. WDS included five dimensions in which each dimension had 2 positive and 2 negative items. These five dimensions were Emotional reaction, Judgments, Behavioural reactions, Personal and Organizational outcomes. These 20 items were measured on a Likert scale of 1 to 5 with 1 being "Strongly Disagree", 2; "Disagree", 3; "Neither Disagree or Agree", 4; "Agree" and 5 being "Strongly Agree". Higher scores meant greater acceptability of diversity in the workplace and positive associations with performance.

\section{2) Employee morale}

Employee morale was evaluated using a developed scale from Linz, et al [18]. Respondents rated each statement using a five-point Likert scale, where 1 is "strongly disagree" and 5 is "strongly agree". These statements were related to organizational commitment [27], job satisfaction [28], and Intention to quit [27], [28].

\section{3) Customer satisfaction}

In this study, DINESERV tool [29] having 29 items (1 item omitted; i.e. "The casual dining restaurant should give support to employees so they can do their jobs well" as it had no concern with the satisfaction of the consumer) was used which is an modified version of SERVQUAL ( 22 items). The DINESERV tool measures the five dimensions of, assurance, reliability, tangibles, responsiveness, and empathy. In DINESERV tool, customers' expectations have "should" statements while the perception scale assesses the service performance of the fast food restaurant under consideration. All the 28 items in perception and expectation instrument have a Likert scale from 1 "strongly disagree" to 5 "strongly agree".

Customer satisfaction in Inkumsah, [30] had been measured through subtracting the expectation scores from the perception score of each of each service attribute.Customer satisfaction can be measured by P-E; where P denotes perceptions while E denotes Expectations; which is called 
disconfirmation-based measures. SQ (service quality) drives customer satisfaction [31] while Parasuraman, Ziethaml, and Berry [32] say that practitioners and the press frequently substitute the words "service quality" and "customer satisfaction". Jain and Gupta, [34] and Parasuraman, et al. [32] have stated certain conceptual, methodological, analytical and practical issues related to SERVQUAL scale and identified that SERVPERF scale has better convergent and discriminant validity, dimensionality and more variance is explained as compared to SERVPERF but claiming the superiority of SERVPERF to SERVQUAL is still arguable (refer to fifth limitation). SERVPERF scale consists of the perceptions towards the service performance i.e. $\mathrm{P}$ part from the SERVQUAL tool. Therefore customer satisfaction in this study was assessed using only the 28 items of perceptions from the DINESERV tool which measures the perceptions on service in a restaurant. These perceptions on service for the fast food restaurant are taken as proxy for customer satisfaction in this study.

\section{Statistical Technique}

Statistical technique used in this study is Structural Equation Modelling (SEM) using Amos 18 version. SEM was applied using two step modelling; in the first stage Confirmatory Factor Analysis (CFA) was run re-specified and in the second stage Structural model paths were then added to show the direct effects of diversity on customer satisfaction through employee morale. Prior to that the data was analysed for normality, outliers and missing values in SPSS 17 version and upon detection they were corrected. Also, discriminant validity, convergent validity, composite reliability, reliability coefficients have been applied and common latent factor and Harman single factor test was applied to test for any method variance in the study

\section{RESULTS}

Total sample size was of 235 respondents out of which 15 outliers were found using Mahalanobis distance test and their values were less than 0.001 . These outliers were removed and the retained data was 220 respondents. Data on 3 variables were collected through the questionnaire. First variable is "employee morale" which consists of 12 items; second variable is "diversity" which consists of 20 items; the third variable "perceptions on service" which consists of 28 items; total 60 items.

\section{A. Mean, Standard Deviations and Intercorrelations}

Table I represents the mean, standard deviation and intercorrelations between the 3 variables. The correlation between employee morale, diversity and perception of satisfaction were insignificant and low.

TABLE I: DESCRIPTIVE STATISTICS: MEAN, SD, AND INTERCORRELATIONS

\begin{tabular}{ccrccc}
\hline \hline Variable & Mean & $\begin{array}{c}\text { Std. } \\
\text { Deviation }\end{array}$ & $\begin{array}{c}\text { Employee } \\
\text { morale }\end{array}$ & Diversity & Perceptions \\
\hline $\begin{array}{c}\text { Employee } \\
\text { morale }\end{array}$ & 3.6617 & 0.55678 & - & & \\
Diversity & 3.1023 & 0.338 & 0.073 & - & \\
Perceptions & 3.8334 & 0.42896 & 0.1 & 0.032 & - \\
\hline \hline
\end{tabular}

$\mathrm{N}=220,{ }^{* 8} \mathrm{p}<0.01,{ }^{*} \mathrm{p}<0.05$
TABLE II: TOTAL VARIANCE EXPLAINED

\begin{tabular}{cccccccc}
\hline \hline & \multicolumn{3}{c}{ Initial Eigen values } & \multicolumn{4}{c}{$\begin{array}{c}\text { Extraction Sums of Squared } \\
\text { Loadings }\end{array}$} \\
\cline { 2 - 7 } & \multicolumn{3}{c}{$\begin{array}{c}\text { \% of } \\
\text { Componant }\end{array}$} & $\begin{array}{c}\text { Cumulative } \\
\%\end{array}$ & $\begin{array}{c}\text { Total of } \\
\text { Variance }\end{array}$ & $\begin{array}{c}\text { Cumulative } \\
\%\end{array}$ \\
\hline 1 & 3.886 & 25.909 & 25.909 & 3.886 & 25.909 & 25.909 \\
2 & 2.475 & 16.501 & 42.41 & 2.475 & 16.501 & 42.41 \\
3 & 1.974 & 13.159 & 55.569 & 1.974 & 13.159 & 55.569 \\
\hline \hline
\end{tabular}

$\overline{\mathrm{KMO}}=0.803$ Bartlett $=0.00$

\section{B. Exploratory Factor Analysis}

Exploratory Factor Analysis was carried out in SPSS 17 before it was taken further in Amos for Confirmatory Factor Analysis. The fundamental assumptions for factor analysis such as KMO (Kaiser-Meyer-Olkin Measure) is 0.803 and Bartlett test of sphericity is less than 0.05.Varimax Algorithm of Orthogonal Rotation was applied to analyse 60 items (12 for employee morale, 20 for diversity and 28 for perceptions on service) for these 3 variables. Table II and Table III shows that 3 factors were fixed and ultimately 15 items ( 7 of employee morale, 4 of diversity, and 4 of perceptions on service) were retained which explained $55.56 \%$ variance in the data. These 3 factors were named employee morale, diversity and perceptions on service and were further taken in AMOS for analysis.

TABLE III: ROTATED COMPONENT MATRIX

\begin{tabular}{lcccc}
\hline \hline & \multicolumn{4}{c}{ Component } \\
\hline Variable & Items & 1 & 2 & 3 \\
\hline Employee Morale & EM2 & 0.811 & & \\
& EM3 & 0.805 & & \\
& EM4 & 0.776 & & \\
& EM6 & 0.706 & & \\
& EM5 & 0.678 & & \\
& EM7 & 0.647 & & \\
Perceptions on & EM1 & 0.642 & & \\
Service & P17 & & 0.808 & \\
& P11 & & 0.801 & \\
& P16 & & 0.796 & \\
Diversity & P12 & & 0.725 & 0.754 \\
& DV11 & & & 0.754 \\
& DV17 & & & 0.748 \\
& DV9 & & & 0.723 \\
& DV15 & & 0.644 \\
\hline \hline
\end{tabular}

\section{Confirmatory Factor Analysis}

Confirmatory factor analysis was used in Amos 18 to confirm the three latent constructs of the 15 observed variables retained from EFA. After three attempts the final hypothesized model was acquired. Table IV gives the summary of the models for the CFA and SEM analysis. The table shows all the goodness of fit indices i.e. CMIN/DF, TLI, CFI, RMSEA along with Chi Square and degrees of freedom. 15 items were taken from EFA (exploratory factor analysis) to AMOS. Four items belonged to "Diversity" (used as diversityy throughout the document due to ellipse issue in AMOS as diversity was already named in SPSS 17 when diversity was summed up for correlation calculation), four to "Perceptions on service" and seven to "Employee Morale". In the first model chi square was 120.612 with $d f=87$, CMIN/DF was 1.386 [must be < 3], TLI was 0.957 [must be $>=0.95$; [35], CFI was 0.964 [must be $>=0.95$; [35]] while RMSEA was 0.042 [must be $<0.06$ to 0.08 ; [35]]. 
TABLE IV: SUMMARY OF MODELS

\begin{tabular}{ccccccc}
\hline \hline & $x 2$ & $d f$ & CMIN/DF & TLI & CFI & RMSEA \\
\hline Measurement Model 1 & 120.612 & 87 & 1.386 & 0.957 & 0.964 & 0.042 \\
$\begin{array}{c}\text { Measurement Model 2 } \\
\text { Hypothesized }\end{array}$ & 101.572 & 86 & 1.181 & 0.98 & 0.983 & 0.029 \\
$\begin{array}{c}\text { Measurement Model } \\
\text { Hypothesized }\end{array}$ & 50.966 & 51 & 0.999 & 1 & 1 & 0 \\
\begin{tabular}{c} 
Structural Model \\
\hline \hline
\end{tabular} & 50.966 & 51 & 0.999 & 1 & 1 & 0 \\
\hline
\end{tabular}

After inspection, it was found that the Modification Indices between the error terms e 21 and e 22 were highly correlating with each other and had values more than 10; (i.e.) MI 17.088 from EM1 and EM2. These two error terms were then correlated in the model using the correlation symbol in AMOS after which the model was re-run the second time.

In the second model chi square was $101.572, d f=86$, CMIN/DF was 1.181 , TLI was 0.98 , CFI was 0.983 and RMSEA was 0.029. Even though the model fit was good even the second time but still there were few values in standardized regression coefficients which were a little less than 0.5 and it affected the reliabilities and validities of the variables therefore they were removed. These items included EM1, EM7 and P12. After removing them the model was re-run the third time. In the third model, the values of chi square were 50.966, $d f=51$, CMIN/DF was 0.999, TLI was 1.000 , CFI was 1.000 and RMSEA was 0.00 . The third model after specification was a great fit. The third model was the final hypothesized model which was taken further for structural analysis (and, mediation).

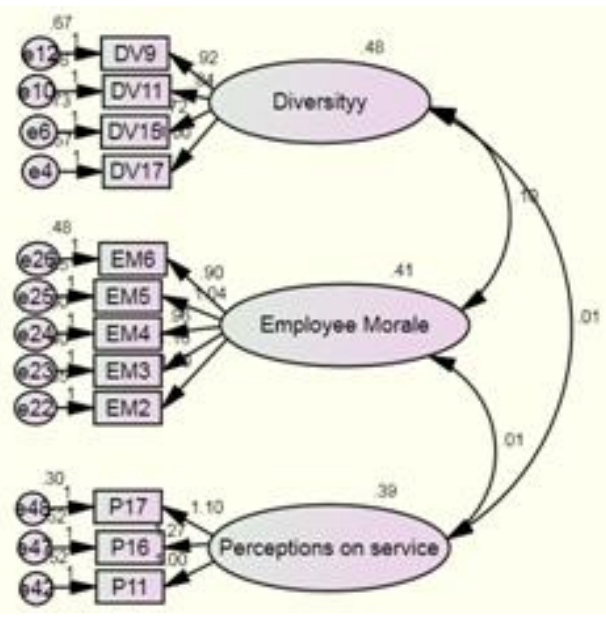

Fig. 2. Results of confirmatory factor analysis. Comparative fit index $=1.000$ Root mean square error of approximation $=0.00$, Chi-square $=50.966 ; d f=51$; $e=$ error

Fig. 2 represents the final model created in AMOS 18 after the re-specifications. The figure shows the relationships between observed and latent variables. Three latent variables Diversity, Employee Morale, and Perceptions on service have been constructed which are explained by 15 observed items. EM1, EM2 and P12 were removed from the analysis as its standardized coefficient was not $>=0.5$ therefore the e21-e22 correlation was also removed automatically. The figure shows the standardized estimates in CFA analysis.

Table V represents the standardized coefficients or factor loadings, unstandardized coefficients and the standard errors for each of the observed variables retained in the final hypothesized model having three latent constructs. DV17, EM2, and P11 were fixed with the value of "1" as regression weights.
TABLE V: STANDARDIZED AND UNSTANDARDIZED COEFFICIENTS FOR CFA

\begin{tabular}{ccccc}
\hline \hline $\begin{array}{c}\text { Observed } \\
\text { Variable }\end{array}$ & Latent Construct & $\beta$ & $B$ & $\mathrm{SE}$ \\
\hline DV17 & Diversity & 0.68 & 1 & \\
DV15 & Diversity & 0.51 & 0.7 & 0.12 \\
DV11 & Diversity & 0.62 & 0.8 & 0.14 \\
DV9 & Diversity & 0.62 & 0.9 & 0.16 \\
EM2 & Employee Morale & 0.73 & 1 & \\
EM3 & Employee Morale & 0.76 & 1.2 & 0.12 \\
EM4 & Employee Morale & 0.75 & 1 & 0.1 \\
EM5 & Employee Morale & 0.67 & 1 & 0.12 \\
EM6 & Employee Morale & 0.64 & 0.9 & 0.11 \\
P11 & Perceptions on Service & 0.66 & 1 & \\
P16 & Perceptions on Service & 0.74 & 1.3 & 0.16 \\
P17 & Perceptions on Service & 0.78 & 1.1 & 0.14 \\
\hline \hline
\end{tabular}

\section{Convergent Validities, Discriminant Validities and Construct Reliabilities}

Convergent validities, discriminant validities and construct reliabilities were calculated and only one validity concern was found. Table VI shows all the validities and reliabilities for the three latent constructs. All construct reliabilities are greater than or equal to 0.7 , while the convergent validities of employee morale and perceptions on service were good as AVE was greater than 0.5except for Diversity which was 0.370 . All the discriminant validities are good as MSV of all the variables was less than AVE. Also ASV is less than both AVE and MSV.

TABLE VI: CONVERGENT VALIDITIES, DISCRIMINANT VALIDITIES AND CONSTRUCT RELIABILITIES

\begin{tabular}{cccccccc}
\hline \hline & CR & AVE & MSV & ASV & $\begin{array}{c}\text { Employee } \\
\text { Morale }\end{array}$ & Diversityy & $\begin{array}{c}\text { Perceptions } \\
\text { on Service }\end{array}$ \\
\hline $\begin{array}{c}\text { Employee } \\
\text { Morale }\end{array}$ & 0.835 & 0.505 & 0.049 & 0.025 & 0.71 & & - \\
$\begin{array}{c}\text { Diversityy } \\
\text { Perceptions } \\
\text { on Service }\end{array}$ & 0.699 & 0.37 & 0.049 & 0.025 & 0.222 & 0.608 & - \\
\hline \hline
\end{tabular}

\section{E. Common Method Variance}

Method variance occurs due to the measurement method and not due to the construct. Measurement error threatens the validity of the study which estimates the associations among measures. The techniques used in this study to identify any common method biases include Harman's single-factor test and Common latent factor test.

Herman single factor test. Herman single factor test was run to identify common method bias. All the 60 items were entered and one factor was fixed to identify how much variance is explained by only one factor. It was found that one factor explained $12.406 \%$ of the data, which shows that common method bias is not a major threat in the data. KMO value 0.728 (must be>0.5) and significance value of Bartlett's test of sphericity 0.00 (must be $<0.05$ ).

Common latent factor. Common latent factor was also run to test the method variance in the data set. All the delta values were less than 0.2 so common method bias was not a major threat in the data.

\section{F. Structural Equation Modelling}

Fig. 3 shows the structural model with chi square 50.966, $d f=51, \mathrm{CMIN} / \mathrm{DF}$ 0.999, TLI 1.000, CFI 1.000, and RMSEA 0.000 (for ref. see Table IV). Table VII shows all the standardized and unstandardized regression coefficients for the mediating path i.e. employee morale between diversity and customer satisfaction. The total effect (path c) of 
diversity on perceptions on service is 0.022 , with $p$ value 0.855 is insignificant, direct effect (path c') is 0.015 with $\mathrm{p}$ value 0.926 is insignificant, and indirect path (ab) is 0.007 with $p$ value 0.545 is also insignificant. The total path, direct and indirect path are insignificant therefore employee morale do not mediate the relationship between diversity and customer satisfaction. Also there was no direct relationship found between diversity and customer satisfaction.

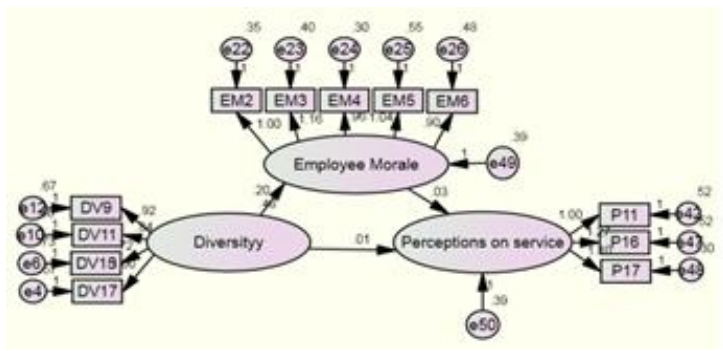

Fig. 3. Hypothesized structural equation model. Comparative fit index $=1.000$; Root mean square error of approximation $=0.000$, Chi-square $=50.966 ; d f=51 ; e=$ error

TABLE VII: RESULTS FROM STRUCTURAL EQUATION MODELLING

\begin{tabular}{ccccccc}
\hline \hline & \multicolumn{2}{c}{$\beta$} & \multicolumn{4}{c}{ B } \\
\hline Model & Diversity & $\begin{array}{c}\text { Employea } \\
\text { Morale }\end{array}$ & Diversity & SE & $\begin{array}{c}\text { Employee } \\
\text { Morale }\end{array}$ & SE \\
\hline $\begin{array}{c}\text { Direct } \\
\text { Employee } \\
\text { Morale }\end{array}$ & 0.222 & & 0.204 & 0.082 & & \\
$\begin{array}{c}\text { Perceptions } \\
\text { on service } \\
\text { Indivect } \\
\text { Employee }\end{array}$ & 0.015 & 0.031 & 0.014 & 0.085 & 0.03 & 0.1 \\
$\begin{array}{c}\text { Morale } \\
\text { Perceptions } \\
\text { on service } \\
\text { Total }\end{array}$ & 0.007 & & & & & \\
$\begin{array}{c}\text { Employee } \\
\text { Morale }\end{array}$ & 0.222 & & 0.006 & 0.018 & & \\
$\begin{array}{c}\text { Perceptions } \\
\text { on service }\end{array}$ & 0.022 & 0.031 & 0.02 & 0.093 & 0.03 & 0.1 \\
\hline \hline p $<0.05^{*}, \mathrm{p}<0.01^{* 8}$ & & & & & & \\
\hline
\end{tabular}

However one intriguing insight was found during the study, that diversity has a positive relationship with employee morale. Path a was found significant in the study with 0.222 standardized regression weight and 0.015 sig value. Also the lower and upper bias corrected point estimate of diversity on employee morale was 0.065 and 0.375 which does not include zero and is therefore significant. The beta shows the positive value not the negative value which was hypothesized in $\mathrm{H} 2$, hence if diversity increases, employee morale also increases. It means that there is greater acceptance, appreciation and value for diversity among the fast food employees as they do not feel discriminated based on ethnicity, race, colour, creed, origin, age, gender and so on.

Table VIII shows all the point estimates and bootstrapping results at $95 \%$ Confidence Interval for all the direct, indirect and total paths in structural equation modelling.

TABLE VIII: POINT ESTIMATES AND BC 95\% CI FOR INDIRECT EFFECTS

\begin{tabular}{lccc}
\hline \hline & & \multicolumn{2}{c}{ Bootstrapping } \\
\cline { 3 - 4 } & Point & \multicolumn{2}{c}{ BC 95\% CI } \\
\cline { 3 - 4 } & Estimate & Lower & Upper \\
\hline Indirect effect (Employee Morale) & 0.006 & -0.015 & 0.045 \\
Direct & 0.014 & -0.162 & 0.16 \\
Total & 0.02 & -0.145 & 0.162 \\
\hline \hline $\mathrm{p}<0.05^{8}, \mathrm{p}<0.01^{* 8}$ & &
\end{tabular}

All the three paths direct, indirect and total areinsignificant and have 0 within the lower and upper confidence intervals. The indirect effect (path ab) was insignificant with point estimate 0.006. The bias corrected (BC) lower and upper confidence interval are -0.015 and 0.045 which means that there is a zero in between therefore employee morale do not mediate the relationship between diversity and customer satisfaction. The total effect (path c) is 0.02 , with -0.145 and 0.162 bias corrected lower and upper confidence interval, a zero in between them indicates that this path is also insignificant, and finally the direct effect (path c') is 0.014 with -0.162 and 0.16 bias corrected BC lower and upper confidence interval and this path is also insignificant as it involves a zero in between.

The measurement and structural model was an idealistic fit. The model tested the relationship between diversity and customer satisfaction mediated through employee morale. The results showed that diversity had no effect, direct, indirect or total on customer satisfaction. Thus there no relationship was found between diversity and customer satisfaction hence any mediation. However, there was a relationship between diversity and employee morale and it was a positive relationship. All the hypotheses have been rejected.

\section{DISCUSSION}

Numerous studies have identified worker and workplace characteristics which affect morale [36], [37], [18]. This study has tested the effect of diversity on customer satisfaction through employee morale. One important precedent of employee morale which has not yet been tested is the perceptions of diversity.

Employee morale is imperative to business operations which leads to increased job satisfaction and efforts, value in the work and dedication to the organization, and the importance of organizational goals than personal goals, thus, increasing organization's performance [23], [18].

In service based organizations, people provide the product. This product is their interaction with customers. Investment in people and technology that supports front-line workers is their prime motive. Thus, exceptional customer service does not happen on its own; rather it has to be created; manifested in the system and in the people. Today, the product of service is different from the products which are manufactured. If customer service is an important concern to an organization, then people have to be important element in solving this concern. To make an organization productive, it needs to motivate its intellectual capital and two motivators are job satisfaction and commitment which are part of employee morale which refer to one's feelings and attitudes towards the job and organization [24].

In this study no relationship was found between employee morale and customer satisfaction but distinguished in the way that this study measures customer satisfaction using DINESERV (perceptions) tool. Nevertheless it gave new insight into the relationship between diversity and employee morale. Notably, the present study substantiated the positive direct effect of diversity on employee morale and diversity appeared as a strong precursor of employee morale in the fast food restaurant setting.

\section{LiMiTATIONS}

Firstly, the sampling unit understudy is not generalizable 
to a larger population because the sample size of 220 respondents is low; also only one city (i.e. Karachi) and one industry (i.e. fast food) was examined in the study.

Secondly, the discriminant validity of diversity is a major issue in the study i.e. the convergent validity is good and there is correspondence between similar items but discriminant validity of diversity is not good it is unable to be distinguished from dissimilar items. It leads to the third limitation which response bias. As most of the front line employees which responded asked for assurity that their jobs will not be jeopardized, also that this information will not be shared with anyone and their names will not be identified. Thus response bias could be because of employees being worried about their job security and reluctance to voice their opinions which lead to false responses or responses with patterns or malingering.

Fourthly, the five dimensions of DINESERV [29] were not used to make five factors in perceptions on service; instead they were all loaded on one factor together. If the five dimensions of reliability, assurance, responsiveness, tangibles and empathy would have been created then it would be a $2^{\text {nd }}$ order CFA and the results may also be changed.

Fifthly, using DINESERV Perceptions (P) adapted version of SERVPERF (for restaurant industry) to measure customer satisfaction may not be accepted by critics as a debate have been going on in the past between SERVQUAL(P-E) and SERVPERF $(\mathrm{P})$ tools. Stating in favour of performance-based measures (SERVPERF), Cronin and Taylor [31] argue that researchers usually evaluate the components of overall satisfaction or perceived quality by customers assess the performance of the business processes of the organization. Despite the fact that evaluating perceptions is a general practise; it does not suggest that performance measures are better than disconfirmation measures. As verified by Parasuraman, Berry \& Zeithaml [33], SQ measurements (P-E) which involve expectations along with perceptions give extensive and detailed information than those that only focuses on perceptions. In addition, the information produced by disconfirmation-measures has greater analytical value and this higher analytical value of SERVQUAL compensates the loss in predictive power as compared to SERVPERF according to Parasuraman, et al. [32].

Lastly, Yap, and Kew [38] differentiated between customer satisfaction and service quality. According to them, customer satisfaction may be an outcome of any dimension besides quality such as needs, equity, perceptions of fairness while dimensions of quality service are specific and based on ideals or excellence. Also customer satisfaction has more conceptual antecedents as compared to service quality. Besides, judgements on satisfaction are based on experience with the service provider while judgements on quality may not [38].

\section{CONCLUSIONS}

In view of the limitations, this study has several implications for future research. Firstly, future researchers can conduct a nationwide study on a larger sample size and on different sampling units which would generalize their findings. Secondly, this study focussed only on frontline employees of different branches of fast food restaurant chains in Karachi. The proposed model of diversity can also be implemented in other departments in the head offices of these restaurant chains, different service industries, different types of restaurants or in various value chain activities or intermediaries in the supply chain and marketing field. Thirdly, with respect to measurement issues, this study used a questionnaire for collection of data; future research may use other methodologies to reduce response bias and increase discriminant validity and reliability of diversity. Researchers may adopt "triangulation" (i.e. collecting data using three different methodologies), for e.g. observations, interviews, and self-reported questionnaires so that the reliability of the results of their study may be improved and they may be able to capture the diversity, morale and customer satisfaction issues in depth. Fourthly, the Perceptions on service could be loaded on 5 factors based on the previous organizational literature, and can be tested empirically. Finally, customer satisfaction can be measured using different tools to find any possible relationship between diversity, employee morale and customer satisfaction.

Employee loyalty and customer loyalty strengthens each other, increasing job satisfaction and customer value. Concisely, if employees are more satisfied then so will be customers. HR practices are revealed in employee behaviours, attitudes and feelings, and customer satisfaction. Diversity, employee morale and customer satisfaction gained prominence in organizational literature in the past century, all differently; through this study this new association was tested but unfortunately found no evidence of such an incidence. However, the results of this study provided significant insights into the underlying effect between diversity and employee morale. Future studies may use this model to further test their relationship in other settings.

\section{REFERENCES}

[1] S. C. Kundu, "Managing cross cultural diversity," Delhi Business Review, vol. 2, no. 2, 2001

[2] G. Robinson and K. Dechant, "Building a business case for diversity," The Academy of Management Executive, vol. 11, no. 3, pp. 21-31, 1997.

[3] H. A. Patrick and V. R. Kumar, "Managing workplace diversity issues and challenges," SAGE Open, vol. 2, no. 2, 2012.

[4] S. E. Jackson, K. E. May, and K. Whitney, "Under the dynamics of diversity in decision-making teams," in Team Effectiveness and Decision Making in Organizations, R. A. Guzzo \& E. Salas (Eds.), San Francisco: Jossey-Bass., 1995, pp. 204-261.

[5] J. B. Shaw and E. B. Power, "The effects of diversity on small work group processes and performance," Human Relations, vol. 51, no. 10, pp. 1307-25, 1998.

[6] J. R. W. Joplin and C. S. Daus, "Challenges of leading a diverse workforce," The Academy of Management Executive, vol. 11, no. 3, pp. 32-47, 1997.

[7] N. Cornelius, Human Resource Management: A Managerial Perspective, Cornwall: Thomson Business Press, 1999.

[8] B. D. Netto and A. S. Sohal, "Human resource practices and workforce diversity: An empirical assessment," International Journal of Manpower, vol. 20, no. 8, pp. 530-547, 1999.

[9] J. P. Fernandez, The Diversity Advantage, New York: Lexington Books, 1993.

[10] P. Grace, "Danger-diversity training ahead: Addressing the myths of diversity training and offering alternatives," The 1994 Annual: Developing Human Resources, pp. 189-99, 1994.

[11] R. Hayles and R. A. Mendez, The Diversity Directive, New York McGraw-Hill.

[12] C. Torres and M. Bruxelles, "Capitalizing on global diversity," $H R$ Magazine, pp. 30-33, 1992

[13] M. Simmons, New Leadership for Women and Men - Building an Inclusive Organization, England, Gower Publishing Ltd., 1996. 
[14] N. J. Adler, International Dimensions of Organizational Behaviour, Cincinnati, Ohio: South- Western College Publishing, 1997.

[15] G. Hofstede, Cultures and Organisation: Intercultural Cooperation and Its Importance for Survival: Software of the Mind, London, England: HarperCollins, 1994.

[16] P. Howitt, "Looking inside the labor market: A review article," Journal of Economic Literature, XL, 125-38, 2002.

[17] A. C. Lawrence, The Significance of Industrial Morale for Improved Work Performance, Pretoria: Unisa, 1996

[18] S. J. Linz, L. K. Good, and P. Huddleston, "Worker morale in Russia: An exploratory study," Journal of Managerial Psychology, vol. 21, no. 5, pp. 415-437, 2006.

[19] R. Hershey, Organizational Morale. New York: Kings Point, 1985.

[20] Employee Morale. (May 16, 2013). [Online]. Available: http://www.businessdictionary.com/definition/employee-morale.html

[21] E. Day and M. R. Crask, "Value assessment: The antecedent of customer satisfaction," Journal of Consumer Satisfaction Dissatisfaction and Complaining Behaviour, vol. 13, pp. 52-60, 2000.

[22] E. Cengiz, "Measuring customer satisfaction: Must or not," Journal of Naval Science and Engineering, vol. 6, no. 2, pp. 76-88, 2010.

[23] J. Abbott, "Does employee satisfaction matter? A study to determine whether low employee morale affects customer satisfaction and profits in the business-to-business sector," Journal of Communication management, vol. 7, no. 4, pp. 333-339, 2003.

[24] L. Jerome and B. H. Kleiner, "Employee morale and its impact on service: What companies do to create a positive service experience," Managing Service Quality, vol. 5, no. 6, pp. 21-25, 1995.

[25] P. M. Podsakoff, S. B. MacKenzie, J. Y. Lee, and N. P. Podsakoff, "Common method biases in behavioral research: A critical review of the literature and recommended remedies," Journal of Applied Psychology, vol. 88, no. 5, p. 879, 2003.

[26] K. P. D. Meuse and T. J. Hostager, "Developing an instrument for measuring attitudes toward and perceptions of workplace diversity: An initial report," Human Resource Development Quarterly, vol. 12, no. 1, pp. 33-51, 2001.

[27] J. Cook and T. Wall, "New work attitude measures of trust, organizational commitment and personal need non-fulfilment," Journal of Occupational Psychology, vol. 53, no. 1, pp. 35-53, 1980.

[28] J. R. Hackman and G. R. Oldham, "Development of the job diagnostic survey," Journal of Applied Psychology, vol. 60, no. 2, pp. 159-170, 1975.

[29] H. J. Kim, C. Cahon, and J. Miller, "Assessing service quality in Korean casual-dining restaurants using DINESERV," Journal of Foodservice Business Research, vol. 6, no. 1, pp. 67-86, 2003.
[30] W. A. Inkumsah, "Measuring customer satisfaction in the local ghanaian restaurant industry," European Journal of Business and Management, vol. 3, no. 2, pp. 125-138, 2011.

[31] J. J. Cronin and S. A. Taylor, "Measuring service quality: A Re-examination and extension," Journal of Marketing, vol. 56, pp. $55-68,1992$

[32] A. Parasuraman, V. A. Ziethaml, and L. L. Berry, "Reassessment of expectations as a comparison standard in measuring service quality: Implications for future research," Journal of Marketing, pp. 111-124, 1994.

[33] A. Parasuraman, L. L. Berry, and V. A. Zeithaml, "Guidelines for conducting service quality research," Marketing Research, pp. 34-44, 1990.

[34] S. K. Jain and G. Gupta, "Measuring service quality: SERVQUAL vs. SERVPERF scales," Vikalpa, vol. 29, no. 2, pp. 25-37, 2004.

[35] J. B. Schreiber, A. Nora, F. K. Stage, E. A. Barlow, and J. King, "Reporting structural equation modeling and confirmatory factor analysis results: A review," The Journal of Educational Research, vol. 99, no. 6, pp. 323-338, 2006.

[36] G. F. Koeske and S. A. Kirk, "The effect of characteristics of human service workers on subsequent morale and turnover," Administration in Social Work, vol. 19, no. 1, pp. 15-31, 1995.

[37] D. H. Knight, S. Ahmad, and R. G. Schroeder, "When do feedback, incentive control and autonomy improve morale? The importance of employee-management relationship closeness," Journal of Managerial Issues, vol. 13, no. 4, pp. 466-482, 2001

[38] S. F. Yap and M. L. Kew, "Service quality and customer satisfaction: Antecedents of customer's re-patronage intentions," Sunway Academic Journal, vol. 4, pp. 59-73, 2007.

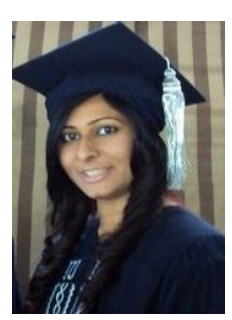

Usmani Sania was born in Karachi, Pakistan on $26^{\text {th }}$ of April 1986. The author's has completed Bachelor in Business Administration (2008) and Master in Business Administration (2010) from Iqra University, Main Campus, Karachi, Pakistan. The specializations in MBA were in 2 field; Finance and Supply Chain Management. Currently doing $\mathrm{PhD}$ from Iqra University in Management.She has worked at Dawlance Pvt Ltd as a senior officer Planning/Receiving. Also she has interned at RBS (Royal Bank of Scotland) in compliance department and Total Atlas Lubricants in supply chain department (distribution). Currently she is working as a Lecturer at Iqra University in Management Sciences Department, Main Campus, Karachi, Pakistan. Her Research Interests are in the field of HR management. 